\title{
Search for Associations of FSHR, INHA, INHAB, PRL, TNP2 and SPEF2 Genes Polymorphisms with Semen Quality in Russian Holstein Bulls (Pilot Study)
}

\author{
Elena Nikitkina *, Anna Krutikova (D), Artem Musidray and Kirill Plemyashov
}

check for updates

Citation: Nikitkina, E.; Krutikova, A.; Musidray, A.; Plemyashov, K. Search for Associations of FSHR, INHA, INHAB, PRL, TNP2 and SPEF2 Genes Polymorphisms with Semen Quality in Russian Holstein Bulls (Pilot Study). Animals 2021, 11, 2882. https://doi.org/10.3390/ani11102882

Academic Editor: Ikhide

G. Imumorin

Received: 10 August 2021

Accepted: 29 September 2021

Published: 2 October 2021

Publisher's Note: MDPI stays neutral with regard to jurisdictional claims in published maps and institutional affiliations.

Copyright: (c) 2021 by the authors Licensee MDPI, Basel, Switzerland. This article is an open access article distributed under the terms and conditions of the Creative Commons Attribution (CC BY) license (https:// creativecommons.org/licenses/by/ $4.0 /)$.
Russian Research Institute of Farm Animal Genetics and Breeding-Branch of the L.K. Ernst Federal Research Center for Animal Husbandry, 55A, Moskovskoye sh., 196625 Saint-Petersburg, Russia; anntim2575@mail.ru (A.K.); 13linereg@mail.ru (A.M.); kirill060674@mail.ru (K.P.)

* Correspondence: nikitkinae@yandex.ru; Tel.: +7-9213039976

Simple Summary: It is important to know the semen quality of sires as quickly as possible. The development of DNA testing methods led to their active introduction into the practice of breeding farm animals. Many studies show that variants of single nucleotide polymorphism loci can be effectively used in as genetic markers in breeding. The aim of our study was to look for the association of polymorphism genes with fresh sperm quality in Russian Holstein bulls. In this pilot study we found that some genotypes of the follicle-stimulating hormone receptor gene are associated with doublet volume, concentration, and the total number of spermatozoa and some genotypes of hormone inhibin gene with higher sperm concentration and volume of ejaculate. Polymorphisms in hormone receptor genes may be good markers of spermatogenesis. This will allow for the finding of bulls with poor sperm quality at an early age.

Abstract: The aim of the study was to search for new mutations in the previously studied gene loci of follicle-stimulating hormone receptor (FSHR), inhibin $\alpha(I N H A)$, inhibin $\beta$ A (INHAB), prolactin $(P R L)$, transition protein 2 (TNP2), and sperm flagella 2 (SPEF2) by sequencing, as well as the search for associations of previously identified mutations at these loci with fresh semen quality in Russian Holstein bulls. Phenotypic data from 189 bulls was collected. Data was analyzed for most bulls for three years of semen collection. The maximum value of each semen quality indicator (doublet ejaculate volume, sperm concentration, progressive motility and total number of spermatozoa) were selected. SNPs were identified in the FSHR, INHA, INHAB, TNP2, SPEF2 genes. The PRL gene did not have polymorphism. Significant $(p<0.05)$ associations of polymorphisms in the FSHR gene with double ejaculate volume, concentration and total number of spermatozoa were identified. Polymorphism in the INHA gene was significantly associated $(p<0.05)$ with sperm concentration. Polymorphism in the INHAB gene was significantly associated $(p<0.05)$ with doublet ejaculate volume and total number of spermatozoa. Polymorphisms in the TNP2 and SPEF2 genes did not have significant associations with semen quality. The SNPs studied in our pilot work may be considered as candidate genetic markers in the selection of bulls.

Keywords: sperm quality; bulls; candidate genes; polymorphism

\section{Introduction}

The widespread use of artificial insemination in cattle breeding implies the need to select bulls based on semen quality [1-3]. In the Russian Federation, bulls from the best parents are selected for breeding stations at the age of 6-10 months [4]. Sometimes bulls have poor semen quality and sperm do not freeze or freeze poorly. Maintaining such bulls at the breeding station is not profitable. Therefore, it is important to look for genetic markers of semen quality in bulls in order to detect such males at an early age [5] before they enter the breeding station. 
Hormones have a decisive influence on the formation and functioning of the reproductive system of animals, both in females and males [6-8]. Hormone receptor gene polymorphisms may be good markers of aspects of spermatogenesis. One of the most significant hormones is follicle-stimulating hormone (FSH), which supports the process of spermatogenesis in bulls [9]. It has been shown that inactivating mutations in the genes of follicle-stimulating hormone $(F S H)$ and its receptor ( FSHR) are causative factors in the occurrence of azoospermia, oligozoospermia and subfertility [10]. A mutation in the FSHR gene, leading to its inactivation, leads to varying degrees of spermatogenic insufficiency in males, but does not entail complete infertility [11]. Knockout of the FSHR gene in mice affects the critical phases of spermatogenesis in males, as their spermatozoa appear dysfunctional, which entails a significant decrease in fertility [12].

The hormone inhibin $\alpha(I N H A)$ is a marker of the Sertoli cell function and exocrine testicular function (spermatogenesis state). Studies in humans have shown that in $100 \%$ of patients with a sperm concentration less than 20 million $/ \mathrm{mL}$, the serum inhibin concentration was below $80.0 \mathrm{pg} / \mathrm{mL}$ at a rate $480.0 \mathrm{pg} / \mathrm{mL}$ [13]. Studies of the influence of hormonal factors on semen quality in bulls showed that the plasma inhibin concentration in the group of bulls with abnormal sperm (morphological defects of sperm, low motility) was lower than in the group with normal sperm $(p<0.05)$ during puberty (at $5,8-13$, $16,17,19$ and 20 months) [14]. Inhibin $\beta$ A (INHBA), as well as inhibin $\alpha$ (INHA), affect the development of spermatogonia, the production of testosterone by Leydig cells, and modulate the pituitary follicle-stimulating hormone [15]. According to the researchers, the genes encoding the inhibins $\alpha$ and $\beta$ (INHA, INHBA) are candidate genes for the analysis of the association with fertility [15]. Thus, in Hanoverian stallions, SNPs and haplotypes in the inhibin $\beta$ A gene (INHBA) are reliably associated with pregnancy rate per estrus and the embryonic and paternal component of breeding values. Mutations identified in the INHBA gene alter binding sites, transcription factors, and can affect the expression of INHBA [16].

The hormone prolactin $(P R L)$ is a regulatory factor in the male reproductive system, and it affects gametogenesis in the testis [17]. Studies of human sperm have shown a direct relationship between the concentration of the hormone prolactin in the seminal plasma and motility and the concentration of sperm [18]. Prolactin has a wide range of effects in mammals. It participates in more than 300 biochemical processes throughout the entire life of the body. It is possible that the results of the analysis of the association of sperm quality parameters with polymorphism in the PRL gene obtained by us are associated with the effect of prolactin on spermatogenic cells, as well as on the production of testosterone by Leydig cells and accessory reproductive glands, which requires further study. Knockout of the $P R L$ gene of mice causes significant changes in the reproductive neuro-endocrine function in males, affects the growth of seminal vesicles and the ventral prostate [19]. The prolactin gene (PRL) and its receptor (PRLR) are candidate genes for searching for associations with the reproductive functions of males, in particular, with sperm quality, since they affect the function of the testes and accessory gonads. SNPs in these genes are associated with fertility traits in stallions [20].

In addition to candidate genes indirectly involved in the formation of the reproductive system of males, research into genes directly involved in spermatogenesis may be promising. One of these is the transition protein 2 (TNP2) gene. Transition proteins, including the TNP2 protein, which are a group of arginine and lysine-rich proteins, replace nucleohistones, and then are replaced by protamines [21], and chromatin condensation is initiated [22]. Biochemical analyzes have shown that the TNP2 protein increases the melting temperature of DNA and promotes the formation of compact DNA packing in the nucleosome nuclei, thus TNP2 is a DNA condensing protein [23]. Knockout of the TNP2 gene in mice confirmed its key role in the formation of sperm structures and functions. TNP2 knockout mice had abnormalities in the structure of the sperm, in particularly with regard to abnormalities of the head and pathology of the acrosome, as well as defects in sperm motility and their inability to penetrate the zona pellucida [24]. Studies of hu- 
man TNP2 gene polymorphism have shown that SNP (rs8043625) is associated with male infertility and apparently affects the splicing processes [25].

The SPEF2 gene (sperm flagella 2) is involved in the formation and development of male germ cells and is a key factor in sperm motility. Expression of the SPEF2 gene was detected in germ cells, Sertoli cells, in the tails of elongated spermatids, and in the tails of mature spermatozoa [26]. A mutation in the SPEF2 gene, expressed by the insertion of a long disseminated element 1 (L1) in intron 30 of the SPEF2 gene is the cause of the sperm defect-ISTS-immobile spermatozoa with a shortened tail in Yorkshire boars. The increased frequency of mutation in the Finnish Yorkshire pig population is associated with a positive effect of L1 insertion into the SPEF2 gene on litter size in the first offspring [27]. The effect of an increase in litter size upon insertion into the SPEF2 gene is also observed in goats [28]; however, the effect of this mutation on goat sperm has not yet been studied. Mutations in the SPEF2 gene, leading to the loss of its function, are also the cause of impaired spermatogenesis in mice [29]. Multiple morphological abnormalities of sperm flagella (MMAF) are a consequence of the expression of a defective SPEF2 protein caused by mutations in the human SPEF2 gene [30].

The aim of the pilot study was to search for associations in the FSHR, INHA, INHAB, $P R L, T N P 2$ and SPEF2 genes polymorphisms with the semen quality in Russian Holstein bulls.

\section{Materials and Methods}

\subsection{Ethics Statement}

The principles of laboratory animal care were followed, and all procedures were conducted according to the ethical guidelines of the L.K. Ernst Federal Science Center for Animal Husbandry (Protocol Number: 2020/2) and the Law of the Russia Federation on Veterinary Medicine No. 4979-1 (14 May 1993).

\subsection{Experimental Animals and Phenotypes}

Phenotypic data from 189 bulls was collected at the Open Joint Stock Company "Nevskoye", Saint-Petersburg, Russia. We used archived data during the period 2007-2018. Bulls lived at the station from six months of age. Semen was collected at intervals of three to four days. Data was analyzed for most bulls for three years of semen collection. For bulls with poor sperm quality, data was evaluated until culling. An average of 145 (from 47 to 215) ejaculates per bull was analyzed. The maximum values of each sperm quality indicator were selected. Sperm quality indicators included semen volume per doublet ejaculate (DVOL, $\mathrm{mL}$ ), sperm concentration (SCON $\times 10^{6} / \mathrm{mL}$ ), progressive motility (PMOT, \%), and total number of spermatozoa (TNS, $\times 10^{8}$ ). The cumulative volume of two ejaculates (DVOL) collected $20 \mathrm{~min}$ apart was assessed indirectly by weight immediately after collection. Sperm concentration was measured with a Photometer SDM $1^{\circledR}$ (Minitüb GmbH, Tiefenbach, Germany) calibrated for bovine. Sperm concentration and progressive motility (PM) were evaluated by a computer-assisted sperm analysis (CASA) in a Mackler chamber at $37^{\circ} \mathrm{C}$. Argus CASA system (ArgusSoft LTD., St. Petersburg, Russia) and a Motic BA 410 microscope (Motic, Hong Kong, China) were used. The total number of spermatozoa was determined by multiplying DVOL by SCON.

\subsection{Isolation of Genomic DNA}

Genomic DNA was isolated from frozen semen samples from 189 animals by the phenol-chloroform method using mercaptoethanol and proteinase $\mathrm{K}$. The resulting DNA was dissolved in TE buffer. The quality and quantity of the obtained DNA was evaluated on a NanoDrop 2000 spectrophotometer (Thermo Scientific, Waltham, MA, USA). The isolated DNA was stored at a temperature of $-20^{\circ} \mathrm{C}$. 


\subsection{PCR Conditions}

PCR was performed in $10 \mu \mathrm{L}$ of the reaction mixture containing $2 \mu \mathrm{L}$ of $5 \times$ Taq buffer (15 mM Mg${ }^{2+}$ ) (Evrogen, Moscow, Russia), $0.2 \mu \mathrm{L}$ of Taq polymerase (Sibenzim, Novosibirsk, Russia), $1.2 \mu \mathrm{L}$ of a mixture of dNTP $(2.5 \mathrm{mM})$ (Thermo Fisher, Waltham, MA, USA), $0.4 \mu \mathrm{L}$ of each of a pair of primers (Syntol, Moscow, Russia), $5.8 \mu \mathrm{L}$ of bi-distilled water, and $0.4 \mu \mathrm{L}$ of genomic DNA $(100 \mathrm{ng} / \mu \mathrm{L})$ as matrices. The reaction was carried out at the following temperature and time parameters: starting denaturation $95^{\circ} \mathrm{C}$ for $5 \mathrm{~min}$; 35 cycles: denaturation $95^{\circ} \mathrm{C}$ for $20 \mathrm{~s}$, annealing of primers-at a temperature specific for each pair of primers for $20 \mathrm{~s}$, elongation $72{ }^{\circ} \mathrm{C}$ for $20 \mathrm{~s}$; final elongation $72{ }^{\circ} \mathrm{C}$ for $5 \mathrm{~min}$ To analyze the sites of the selected genes, the primers used are shown in Table 1.

Table 1. The list of primers used in FSHR, INHA, INHAB, PRL (Sang et al., 2011), TNP2 (Gao et al., 2014) and SPEF2 (Guo et al., 2014) genes.

\begin{tabular}{|c|c|c|c|c|c|}
\hline Gene & Locus & Primer Sequence $\left(5^{\prime}>3^{\prime}\right)$ & $\mathrm{AT}\left(\mathrm{C}^{0}\right)$ & RE & $\begin{array}{c}\text { RES, } \\
\text { bp/Genotype }\end{array}$ \\
\hline FSHR & $5^{\prime}$-upstream region & $\begin{array}{c}\text { F:TGTTCCCACTGACTCAGATACTT } \\
\text { R:TCCCTGCCCTTCAGTGACGAA }\end{array}$ & 61 & $\operatorname{Taq} \mathrm{I}$ & $\begin{array}{c}\text { AA: } 446,97,71 \\
\text { AT: } 517,446,97,71 \\
\text { TT: } 517,97\end{array}$ \\
\hline INHA & Part of exon 1 & $\begin{array}{l}\text { F:ATTCAACCCAACCTGCCTA } \\
\text { R:GCCCTGTTTCTGGATGCC }\end{array}$ & 61 & Msp I & $\begin{array}{c}\text { AA: } 123,95,31 \\
\text { AG: } 123,95,79,44, \\
31 \\
\text { GG: } 95,79,44,31\end{array}$ \\
\hline$I N H A B$ & Intron 1 & $\begin{array}{l}\text { F: CAGGGTTTCAGAAGTTGG } \\
\text { R:GGTGGTTGTTACTGTTTATC }\end{array}$ & 61 & Seq $^{1}$ & \\
\hline$P R L-1$ & Complete of exon 4 & $\begin{array}{l}\text { F:GAGATTGTTTCTTGTGGTTGTTCAG } \\
\text { R:TTCAAAACTCATTCCTCATTACAGA }\end{array}$ & 62 & $R s a \mathrm{I}$ & $\begin{array}{c}284 \\
\mathrm{n} / \mathrm{p}^{2}\end{array}$ \\
\hline$P R L-2$ & Part of exon 5 & $\begin{array}{l}\text { F:GATAAATAGAAAGAACAAAGATGAG } \\
\text { R:AACCCATTAGAGCCAAGC }\end{array}$ & 60 & AluI & $\begin{array}{c}372 \\
\mathrm{n} / \mathrm{p}^{2}\end{array}$ \\
\hline TNP2 & $3^{\prime}$-upstream region & $\begin{array}{l}\text { F:ACTGGACCAATGAACGAA } \\
\text { R:CTCCCTACCCAACCTCTT }\end{array}$ & 61 & HindIII & $\begin{array}{c}\text { TT: } 432,103 \\
\text { TC: } 535,432,103 \\
\text { CC: } 535\end{array}$ \\
\hline SPEF2 & $5^{\prime}$-upstream region & $\begin{array}{l}\text { F: TAATCCTCCACCAGAATCTG } \\
\text { R:GCCTTATGATGTGGGTATGA }\end{array}$ & 61 & TaqI & $\begin{array}{c}\text { TT: } 584 \\
\text { TG: } 584,460,124 \\
\text { GG: } 460,124\end{array}$ \\
\hline
\end{tabular}

AT—annealing temperature of primers; RE—restriction enzyme; RES—restriction fragment size. ${ }^{1}$ —sequence only. ${ }^{2}$ — not polymorphic. bp—base pairs.

\subsection{Sequencing and RFLP Reactions}

A portion of each sample was sequenced on an Applied Biosystems 3500 Genetic Analyzer using the BigDye ${ }^{\circledR}$ Terminator v3.1 Sequencing Standard Kit (Applied Biosystems, Foster City, CA, USA) according to the manufacturer's protocol. Genotyping was then performed by PCR-RFLP. The mutations in the regions of the studied genes were identified using the restriction endonucleases FSHR-TaqI, INHA-MspI, TNP2-HindIII, and SPEF2-TaqI. The PCR product was cleaved using $2 \mathrm{U}$ of each restriction enzyme for $2 \mathrm{~h}$ at $65^{\circ} \mathrm{C}$ (for $\mathrm{TaqI}$ ) and $37^{\circ} \mathrm{C}$ (for the rest). Fragments were detected on a $2 \%$ agarose gel with ethidium bromide. Two sections of the PRL gene were analyzed by sequencing only.

\subsection{Statistical Analyses}

Data was analysed by ANOVA using IBM SPSS Statistics 19 (IBM, Armonk, NY, USA) and Statistica 10 (TIBCO Software Inc., Palo Alto, CA, United States). The data were expressed as means \pm standard deviation. All pairwise multiple comparisons between means were conducted by $t$-test. To control the type 1 error a Bonferroni test was performed. Differences were considered statistically significant at $p<0.05$. 


\section{Results}

The maximum values of the studied indicators of semen quality varied between bulls. The maximum DVOL varied from 3 to $27 \mathrm{~mL}$, the maximum sperm concentration was from $700 \times 10^{6} / \mathrm{mL}$ to $2000 \times 10^{6} / \mathrm{mL}$, and the total number of spermatozoa was from $2.7 \times 10^{8}$ to $26.4 \times 10^{8}$ in different bulls. This enabled bulls with contrasting semen quality indicators to be selected for PCR and sequencing.

Three new SNPs in exons 4 and 5 of the PRL gene discovered by L. Sang et al. (2011) could not be detected by RFLP using the restriction enzymes RsaI, AluI and AciI, while sequencing showed the absence of these SNPs in our samples of Russian Holstein bulls.

The single nucleotide polymorphism of C7639T (rs43408735) in intron 1 of the INHAB gene, declared by other researchers, was not detected by us. However, at this point of this locus, according to the international genetic database Ensembl and according to the results of our sequencing, there is an SNP identified as A > G (rs43408735) [31]. This polymorphism is not detected by the TaqI endonuclease since none of the polymorphic variants forms a restriction site.

Polymorphism in FSHR (Figure 1), TNP2 (Figure 2), SPEF2 (Figure 3), and INHA (Figure 4), INHAB genes was found. The frequency of genotypes and alleles were calculated by direct counting (Table 2). TT genotype of FSHR gene was rare. CC and CT genotypes in TNP2 gene were also rare. AA genotype in INHA gene was not found.

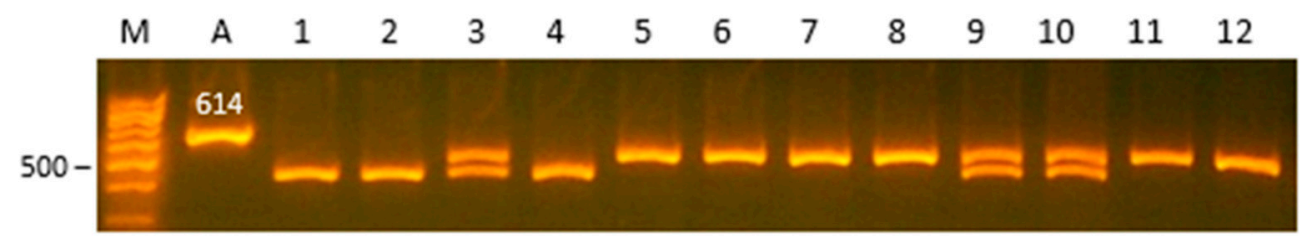

Figure 1. The TaqI polymorphism g.234500 A > T in gene FSHR: 1, 2, 4-genotype AA (446, 97, 71 bp);3, 9, 10-genotype AT (517, 446, 97, 71 bp); 5-8, 11, 12-genotype TT (517, 97 bp); A-amplicon; $\mathrm{M}$-marker.

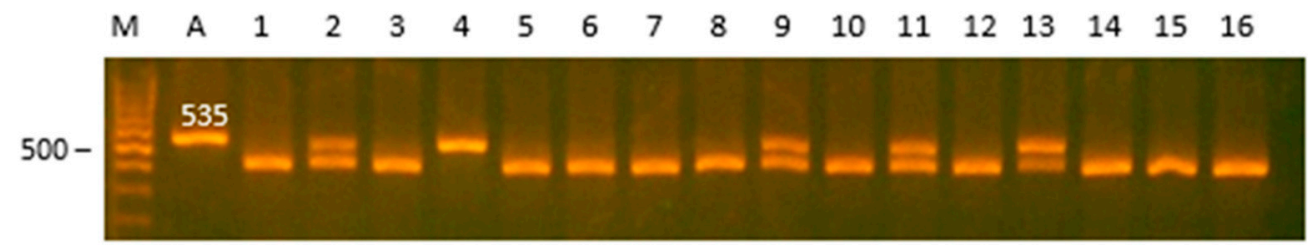

Figure 2. The HindIII polymorphism g.1536 C > T in gene TNP2: 1, 3, 5-8, 10, 12, 14-16-genotype TT (432, 103 bp); 2, 9, 11, 13-genotype CT (535, 432, 103 bp); 4-genotype CC (535 bp); A-amplicon; $\mathrm{M}$-marker.

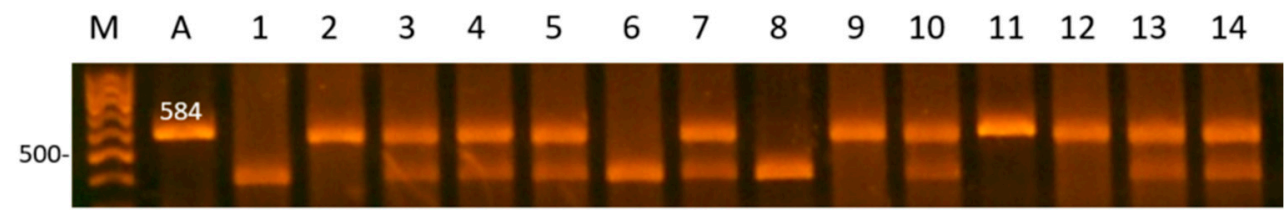

Figure 3. The TaqI polymorphism c.2851 G > T in gene SPEF2: 2, 9, 11, 12-genotype TT (584 bp); 3-5, 7, 10, 13, 14-genotype GT (584, 460, 124 bp); 1, 6, 8-genotype GG (460, 124 bp); A-amplicon; $\mathrm{M}-$ marker.

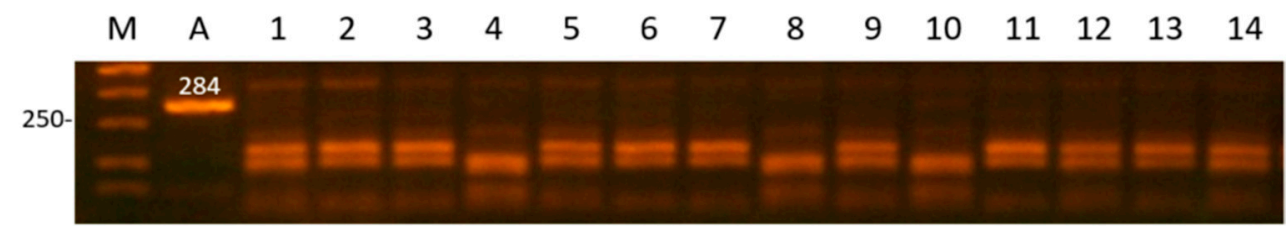

Figure 4. The MspI polymorphism c.192 A > G in gene IHNA: 1-3, 5-7, 9, 11-14-genotype AG (123, 95, 79, 44, 31 bp); 4, 8, 10-genotype GG (95, 79, 44, 31bp); A-amplicon; M-marker. 
Table 2. Frequency of genotypes and alleles of FSHR, INHA, INHAB, TNP2 and SPEF2 genes in Russian Holstein bulls.

\begin{tabular}{|c|c|c|c|}
\hline Gene & Genotype & Frequency of Genotypes & Alleles \\
\hline \multirow{3}{*}{$\begin{array}{c}F S H R \\
\text { (rs43676359) }\end{array}$} & AA (69) & 0.365 & A-0.651 \\
\hline & AT (108) & 0.571 & T-0.349 \\
\hline & $\mathrm{TT}(12)$ & 0.063 & \\
\hline \multirow{3}{*}{$\begin{array}{c}I N H A \\
\text { (rs41257116) }\end{array}$} & $\mathrm{AA}(0)$ & 0.000 & A-0.413 \\
\hline & AG (156) & 0.825 & G-0.587 \\
\hline & GG (33) & 0.175 & \\
\hline \multirow{3}{*}{$\begin{array}{c}I N H A B \\
(\mathrm{rs} 43408735)\end{array}$} & AA (69) & 0.365 & A-0.569 \\
\hline & AG (77) & 0.407 & G-0.431 \\
\hline & GG (43) & 0.227 & \\
\hline \multirow{3}{*}{$\begin{array}{c}\text { TNP2 } \\
\text { (g.1536) }\end{array}$} & CC (21) & 0.111 & C-0.196 \\
\hline & CT (32) & 0.169 & T-0.804 \\
\hline & TT (136) & 0.720 & \\
\hline \multirow{3}{*}{$\begin{array}{c}\text { SPEF2 } \\
\text { (c. } 2851 \mathrm{G}>\mathrm{T})\end{array}$} & GG (65) & 0.344 & G-0.603 \\
\hline & GT (98) & 0.518 & T-0.397 \\
\hline & TT (26) & 0.138 & \\
\hline
\end{tabular}

Note: Figure in brackets are the number of samples.

Descriptive statistics for the semen quality traits are listed in Table 3. Only the maximum values of the traits for each bull are included in the analysis. From the data in the table it can be seen that the quality of the sperm was different.

Table 3. Descriptive statistics for the semen quality traits.

\begin{tabular}{ccccc}
\hline Gene & DVOL $(\mathbf{m L})$ & SCON $(\times \mathbf{1 0} \mathbf{8} / \mathbf{m L})$ & TNS $\left(\times \mathbf{1 0}^{\mathbf{8}}\right)$ & PMOT $(\mathbf{\%})$ \\
\hline Number of samples & 189 & 189 & 189 & 189 \\
\hline means & 16.3 & 1.45 & 24.16 & 85.9 \\
\hline standard deviation & 5.0 & 0.22 & 13.5 & 4.9 \\
\hline minimum & 3 & 0.70 & 2.7 & 80.0 \\
\hline maximum & 27 & 2.00 & 46.0 & 90.0
\end{tabular}

Note: semen volume per doublet ejaculate (DVOL, $\mathrm{mL}$ ), sperm concentration $(\mathrm{SCON} \times 108 / \mathrm{mL})$, progressive motility (PMOT, \%), the total number of spermatozoa (TNS, $\times 108)$. Figure in brackets is the number of samples. The dates are expressed as means \pm standard deviation.

The results of association analysis between FSHR, INHA, INHAB, TNP2 and SPEF2 genotypes and sperm quality traits are shown in Table 4. Bulls with the AA (FSHR) (rs43676359) genotype had a significantly $(p<0.05)$ higher doublet volume, concentration, and the total number of spermatozoa than did those with the TT genotype.

Bulls with the genotype GG (INHA) (rs41257116) had a higher cell concentration than did bulls with the genotype AG $(p<0.05)$. No significant differences in ejaculate volume and motility were found. However, bulls with the GG genotype had greater ejaculate volume and higher motility than bulls with the AG genotype.

Bulls with the genotype AA (INHAB) had the highest doublet ejaculate volume $(19.24 \pm 6.35 \mathrm{~mL})$ and total number of spermatozoa $(32.54 \pm 8.59 \mathrm{mln})$ compared to bulls with the genotypes AG $(16.45 \pm 8.67 \mathrm{~mL}$ and $23.35 \pm 4.32 \mathrm{mln})$ and $\mathrm{GG}(11.32 \pm 7.57 \mathrm{~mL}$ and $14.85 \pm 1.98 \mathrm{mln})(p<0.05)$. No significant differences were found in the concentration of spermatozoa and motility. However, bulls with the AA genotype had the greatest concentration and motility. The bulls with the GG genotype had the poorest semen quality.

There were no significant differences for all studied parameters in bulls with different genotypes for the TNP2 and SPEF2 genes. 
Table 4. Distribution of semen quality traits by genotypes FSHR, INHA, INHAB, TNP2 and SPEF2 genes genotypes in Russian Holstein bulls.

\begin{tabular}{cccccc}
\hline Gene & Genotype & DVOL $(\mathbf{m L})$ & SCON $\left(\times \mathbf{1 0} \mathbf{8}^{\mathbf{m L}}\right)$ & TNS $\left(\times \mathbf{1 0}^{\mathbf{8}}\right)$ & PMOT (\%) \\
\hline FSHR & AA (69) & $17.2 \pm 5.43^{\mathrm{a}}$ & $1.41 \pm 0.21^{\mathrm{a}}$ & $25.8 \pm 10.55^{\mathrm{a}}$ & $86.3 \pm 5.21$ \\
& AT (108) & $16.8 \pm 7.23$ & $1.45 \pm 0.27$ & $25.2 \pm 14.83$ & $84.3 \pm 4.27$ \\
& TT (12) & $11.965 \pm 7.58^{\mathrm{b}}$ & $1.29 \pm 0.32^{\mathrm{b}}$ & $15.6 \pm 12.16^{\mathrm{b}}$ & $82.9 \pm 5.13$ \\
\hline \multirow{2}{*}{ INHA } & AG (156) & $16.56 \pm 5.67$ & $1.39 \pm 0.26^{\mathrm{a}}$ & $23.55 \pm 12.54$ & $84.24 \pm 4.67$ \\
& GG (33) & $17.20 \pm 6.83$ & $1.71 \pm 0.29^{\mathrm{b}}$ & $28.43 \pm 13.76$ & $86.76 \pm 5.59$ \\
\hline INHAB & AA (69) & $19.24 \pm 6.35^{\mathrm{a}}$ & $1.45 \pm 0.22$ & $32.54 \pm 8.59^{\mathrm{a}}$ & $87.13 \pm 4.43$ \\
& AG (77) & $16.45 \pm 8.67^{\mathrm{b}}$ & $1.46 \pm 0.33$ & $23.35 \pm 4.32^{\mathrm{b}}$ & $83.21 \pm 5.24$ \\
& GG (43) & $11.32 \pm 7.57^{\mathrm{b}}$ & $1.30 \pm 0.31$ & $14.85 \pm 1.98^{\mathrm{b}}$ & $83.56 \pm 5.37$ \\
\hline \multirow{2}{*}{ TNP2 } & CC (21) & $14.70 \pm 8.65$ & $1.35 \pm 0.36$ & $19.64 \pm 16.93$ & $83.48 \pm 5.56$ \\
& CT (32) & $14.50 \pm 9.72$ & $1.26 \pm 0.36$ & $19.29 \pm 16.06$ & $86.23 \pm 5.49$ \\
& TT (136) & $16.21 \pm 7.74$ & $1.43 \pm 0.24$ & $25.37 \pm 12.23$ & $85.57 \pm 5.34$ \\
\hline SPEF2 & GG (65) & $16.34 \pm 7.87$ & $1.41 \pm 0.23$ & $23.33 \pm 12.74$ & $84.83 \pm 5.23$ \\
& GT (98) & $17.00 \pm 7.89$ & $1.43 \pm 0.23$ & $25.84 \pm 12.20$ & $85.30 \pm 4.89$ \\
& TT (26) & $15.46 \pm 9.64$ & $1.38 \pm 0.42$ & $23.38 \pm 17.99$ & $85.12 \pm 5.49$ \\
\hline
\end{tabular}

Note: semen volume per doublet ejaculate (DVOL, $\mathrm{mL}$ ), sperm concentration (SCON $\times 10^{8} / \mathrm{mL}$ ), progressive motility (PMOT, \%), the total number of spermatozoa (TNS, $\times 10^{8}$ ). Figure in brackets is the number of samples. The dates are expressed as means \pm standard deviation. ${ }^{\mathrm{ab}}-p<0.05$.

\section{Discussion}

In our study, we did not take into account many other factors, especially the age of the bull and the season of the year. An average of 145 (from 47 to 215) ejaculates per bull was analyzed. The analysis took the maximum values of sperm quality traits, which were for three years of semen collection. Therefore, we decided not to include the other factors in the analysis. The bulls were all in the same condition.

Polymorphism in two sections of the PRL gene was not detected in our study. However, the studies of the Chinese population of Holstein bulls showed the presence of three SNPs in these areas. Two mutations were identified, one in exon 4 (A7550G and C7661T) and one in exon 5 (T8370C). Despite the presence of a high level of polymorphism in the three SNPs, no statistically significant effect on sperm quality was detected [32].

Our data partly coincides with the Chinese Holstein data with respect to the influence of the FSHR gene on semen quality. In their studies, Holstein bulls with AA genotype also had significantly $(p<0.05)$ higher ejaculate volumes and concentrations [32], although they did not take the total number of spermatozoa into account. There were no significant differences between heterozygotes and homozygotes in our work. However, semen quality was better in bulls with the heterozygous AT genotype than in homozygous TT bulls. Such an effect of a single nucleotide substitution in the $5^{\prime}$-upstream region of the FSHR gene can occur due to a change in the level of transcriptional activity [33] as a result of changes in the transcription factor binding sites. Such changes lead to a decrease in the level of FSHR gene expression, which, in turn, affects spermatogenesis. Further research is needed involving a larger number of bulls, especially ones with the TT genotype.

The INHA gene is associated with histological maturation of the testes and, thus, has a significant effect on bovine fertility [34]. Thus, variants of polymorphism in the INHA gene could be candidate mutations for sperm quality. In addition, the A192G SNP in the INHA gene is associated with spermatozoa respiration [32]. The mutation in the INHA gene revealed by us in Russian Holstein bulls is synonymous, which does not lead to amino acid replacement. Despite this, however, it is believed that the mutation affects the expression of the INHA gene and the stability of INHA transcription, which leads to a decrease in the concentration of inhibin. This leads to an increase in FSH concentration due to impaired feedback from the pituitary gland [35]. Also, a synonymous nucleotide substitution can affect the proper formation of protein structures during biosynthesis, 
which, accordingly, will affect gene expression, protein function and phenotype [36]. In our studies, bulls with the AA genotype were not identified. Bulls with the genotype GG had a higher sperm concentration than bulls with the genotype AG $(p<0.05)$. No significant differences in ejaculate volume and motility were found. Obviously, differences in sperm quality are associated with the effect of mutations on the regulatory functions of inhibin on cell proliferation during spermatogenesis. This is confirmed by studies showing that the level of inhibin positively correlates with sperm concentration [37]. The lack of statistical certainty is probably associated with a small number of individuals with a certain genotype.

Using immunohistochemical analysis, INHAB was detected in Sertoli cells, Leydig cells, and testicular endothelial cells of newborn rats three to nine days old [38]. INHAB has been associated with the proliferation of immature Sertoli cells and the differentiation of spermatogonia [38-40]. The INHAB protein can regulate the processes of gametogenesis in immature and adult testes, and also affect Sertoli cells [41]. For male pigs, polymorphisms in the INHAB gene are markers of boar fertility, since they are associated with sperm plasma quality and sperm rate. As a result of studying the INHAB gene by Chinese scientists, four SNPs were found (C7639T (rs43408735), G7550A, C7661T, T8370C), three of which were first identified. However, only one of these $\mathrm{C} 7639 \mathrm{~T}$ polymorphisms, according to the authors, had a significant relationship with ejaculate volume, sperm concentration and motility $(p<0.05)$ [32]. In our studies, the same region of the INHAB gene was sequenced, as a result of which only one nucleotide substitution A > G (rs43408735) was identified. The substitution is located in intron 1 and does not lead to a change in the amino acid composition of the protein; however, the proximity to the exon can affect the splicing process. The frequency of the alleles in our studies was $\mathrm{A}-0.55, \mathrm{G}-0.45$, which differs from the population data in the ENSEMBL database, where the frequency of alleles was $\mathrm{A}-0.31, \mathrm{G}-0.69$. The frequency of occurrence of genotypes according to our data was AA-0.35, AG-0.40, GG-0.25.

The TNP2 protein is a transitional protein and is involved in the removal of histones and chromatin condensation during sperm formation and maturation [42]. Gao Q. et al. (2014) revealed that bulls with the CT genotype in the TNP2 gene are characterized by higher volumes of ejaculate and more motile sperm after thawing than in bulls with CC genotype, as the T >C mutation in the $3^{\prime}$-UTR region affects the expression of TNR2 mRNA, which determines significant differences in sperm quality. Our studies confirm this work in that bulls with the CC genotype had the lowest ejaculate volume and motility compared with the other genotypes. However, differences in our study were not significant. Bulls with the TT genotype had the highest semen quality (VOL, SCON and TNS) in contrast to the results of Gao et al. [42]. In their studies, bulls with the CT genotype had the best semen qualities. In our studies, there were no significant differences in bulls with different genotypes for the TNP2 gene, which may be due to the small number of animals involved.

The SPEF2 gene plays a significant role in the formation and development of the sperm tail. Mutations in this gene lead to impaired spermatogenesis, the appearance of tail defects and, accordingly, impaired sperm motility [29]. Mutations in the SPEF2 gene, which has a complex structure and consists of 36 exons and 35 introns, leads to alternative splicing and, as a result, the loss of protein functions that play a role in spermatogenesis and testicular development, leading to sperm immobility [43]. In our studies, there were no significant differences in semen quality in bulls with different genotypes for the SPEF2 gene. However, bulls with the heterozygous genotype TG had higher values for all the studied parameters than those with the homozygotes GG and TT. The single nucleotide substitution in the SPEF2 gene leads to alternative splicing and, as a result, to two alternative variants of the $S P E F 2$ protein. A combination of two alternative proteins probably contributes to a more efficient formation of sperm motility factors during spermatogenesis. It has been noted that bulls with the GG genotype had the greatest sperm motility and fewer defects [44]. However, as these studies were conducted on frozen-thawed semen it is possible that this polymorphism also affects the preservation of sperm during cryopreservation. At 
present, the molecular mechanisms of regulation of this process by the SPEF2 protein remain unknown [44].

\section{Conclusions}

When analyzing the results of our pilot studies on the search for associations between single nucleotide substitutions in the genes responsible for the reproductive function of bulls, it is necessary to take into account that prolonged use of artificial insemination contributes to the natural elimination of undesirable infertility genotypes from the population. This process is due to the selection of bulls with the best semen quality for further reproduction. Thus, the frequency of occurrence of genotypes unfavorable for the qualitative characteristics of sperm is significantly reduced, which can affect the results of statistical analysis in such studies. However, semen from bulls of outstanding genetic production potential, with albeit insufficiently high genetically determined indicators of semen quality, is undoubtedly so widely used as to perpetuate valuable genetic material. Therefore, genotypes undesirable for semen quality are found in the population. The SNPs studied in our work in genes that affect the reproductive function of bulls can be considered as a candidate for its use in identifying molecular genetic markers in the selection of young bulls. The study of the molecular basis of the influence of these mutations should allow a deeper understanding of the principles of the formation of fertility in bulls.

Author Contributions: Conceptualization, E.N. and A.K.; methodology, A.K.; formal analysis, A.M.; investigation, A.M., E.N. and A.K.; writing—original draft preparation, E.N.; writing-review and editing, K.P.; supervision, K.P. All authors have read and agreed to the published version of the manuscript.

Funding: This research was funded by Ministry of Science and Higher Education of the Russian Federation, project No. 121052600354-7 (0445-2021-0011).

Institutional Review Board Statement: The study was conducted according to the guidelines of the Declaration of Helsinki, and guidelines of the L.K. Ernst Federal Science Center for Animal Husbandry and the Law of the Russia Federation on Veterinary Medicine No. 4979-1 (14 May 1993).

Data Availability Statement: Data will be made accessible from corresponding authors upon reasonable request.

Acknowledgments: The authors acknowledge Peter Chenoweth, James Cook University, Vice President, Association for Applied Animal Andrology for providing language help and for proofreading the article.

Conflicts of Interest: The authors declare no conflict of interest.

\section{References}

1. Murphy, E.M.; Kelly, A.K.; O’Meara, C.; Eivers, B.; Lonergan, P.; Fair, S. Influence of bull age, ejaculate number, and season of collection on semen production and sperm motility parameters in holstein friesian bulls in a commercial artificial insemination centre. J. Anim. Sci. 2018, 96, 2408-2418. [CrossRef]

2. Schenk, J.L. Review: Principles of maximizing bull semen production at genetic centers. Animal 2018, 12, s142-s147. [CrossRef] [PubMed]

3. Olsen, H.B.; Heringstad, B.; Klemetsdal, G. Genetic analysis of semen characteristic traits in young Norwegian Red bulls. J. Dairy Sci. 2020, 103, 545-555. [CrossRef] [PubMed]

4. Saksa, E.I. Efficiency of use of bulls evaluated by various methods for improvement of highly productive herds. Dairy Beef Cattle Breed. 2018, 1, 5-8.

5. Yin, H.; Fang, L.; Qin, C.; Zhang, S. Estimation of the genetic parameters for semen traits in Chinese Holstein bulls. BMC Genet. 2019, 20. [CrossRef] [PubMed]

6. Zhao, W.; Jing, J.; Shao, Y.; Zeng, R.; Wang, C.; Yao, B.; Hang, D. Circulating sex hormone levels in relation to male sperm quality. BMC Urol. 2020, 20. [CrossRef]

7. Salas-Huetos, A.; Maghsoumi-Norouzabad, L.; James, E.R.; Carrell, D.T.; Aston, K.I.; Jenkins, T.G.; Becerra-Tomás, N.; Javid, A.Z.; Abed, R.; Torres, P.J.; et al. Male adiposity, sperm parameters and reproductive hormones: An updated systematic review and collaborative meta-analysis. Obes. Rev. 2021, 22. [CrossRef] 
8. Sun, L.P.; Du, Q.Z.; Song, Y.P.; Yu, J.N.; Wang, S.J.; Sang, L.; Song, L.W.; Yue, Y.M.; Lian, Y.Z.; Zhang, S.L.; et al. Polymorphisms in luteinizing hormone receptor and hypothalamic gonadotropin-releasing hormone genes and their effects on sperm quality traits in Chinese Holstein bulls. Mol. Biol. Rep. 2012, 39, 7117-7123. [CrossRef]

9. Pengo, M.; Ferlin, A.; Arredi, B.; Ganz, F.; Selice, R.; Garolla, A.; Foresta, C. FSH receptor gene polymorphisms in fertile and infertile Italian men. Reprod. Biomed. Online 2006, 13, 795-800. [CrossRef]

10. Huhtaniemi, I. Mutations along the pituitary-gonadal axis affecting sexual maturation: Novel information from transgenic and knockout mice. Mol. Cell. Endocrinol. 2006, 254-255, 84-90. [CrossRef]

11. Tapanainen, J.S.; Aittomäki, K.; Min, J.; Vaskivuo, T.; Huhtaniemi, I.T. Men homozygous for an inactivating mutation of the follicle-stimulating hormone (FSH) receptor gene present variable suppression of spermatogenesis and fertility. Nat. Genet. 1997, 15, 205-206. [CrossRef]

12. Krishnamurthy, H.; Danilovich, N.; Morales, C.R.; Sairam, M.R. Qualitative and quantitative decline in spermatogenesis of the follicle- stimulating hormone receptor knockout (FORKO) mouse. Biol. Reprod. 2000, 62, 1146-1159. [CrossRef]

13. Von Eckardstein, S.; Simoni, M.; Bergmann, M.; Weinbauer, G.F.; Gassner, P.; Schepers, A.G.; Nieschlag, E. Serum inhibin B in combination with serum follicle-stimulating hormone (FSH) is a more sensitive marker than serum FSH alone for impaired spermatogenesis in men, but cannot predict the presence of sperm in testicular tissue samples. J. Clin. Endocrinol. Metab. 1999, 84, 2496-2501. [CrossRef] [PubMed]

14. Weerakoon, W.W.P.N.; Sakase, M.; Kawate, N.; Hannan, M.A.; Kohama, N.; Tamada, H. Plasma IGF-I, INSL3, testosterone, inhibin concentrations and scrotal circumferences surrounding puberty in Japanese Black beef bulls with normal and abnormal semen. Theriogenology 2018, 114, 54-62. [CrossRef] [PubMed]

15. Hiendleder, S.; Dodds, K.G.; Wassmuth, R. Linkage mapping of the ovine $\alpha$-inhibin (INHA), $\beta(A)$-inhibin/activin (INHBA), and $\beta(B)$-inhibin/activin (INHBB) genes. J. Hered. 2000, 91, 343-345. [CrossRef]

16. Giesecke, K.; Hamann, H.; Sieme, H.; Distl, O. INHBA-Associated markers as candidates for stallion fertility. Reprod. Domest. Anim. 2010, 45, 342-347. [CrossRef] [PubMed]

17. Bartke, A. Prolactin in the male: 25 Years later. J. Androl. 2004, 25, 661-666. [CrossRef] [PubMed]

18. Aiman, J.; McAsey, M.; Harms, L. Serum and seminal plasma prolactin concentrations in men with normospermia, oligospermia, or azoospermia. Fertil. Steril. 1988, 49, 133-137. [CrossRef]

19. Steger, R.W.; Chandrashekar, V.; Zhao, W.; Bartke, A.; Horseman, N.D. Neuroendocrine and reproductive functions in male mice with targeted disruption of the prolactin gene. Endocrinology 1998, 139, 3691-3695. [CrossRef]

20. Giesecke, K.; Hamann, H.; Sieme, H.; Distl, O. Evaluation of prolactin receptor (prlr) as candidate gene for male fertility in hanoverian warmblood horses. Reprod. Domest. Anim. 2010, 45. [CrossRef]

21. Meistrich, M.L. Nuclear Morphogenesis during Spermiogenesis. In Molecular Biology of the Male Reproductive System; Academic Press: Cambridge, MA, USA, 1993; pp. 67-97.

22. Meistrich, M.L. Histone and basic nuclear protein transitions in mammalian spermatogenesis. In Histones and Other Basic Nuclear Proteins; CRC Press: Boca Raton, FL, USA, 1989; pp. 165-182.

23. Baskaran, R.; Rao, M.R.S. Interaction of spermatid-specific protein TP2 with nucleic acids, in vitro. A comparative study with TP1. J. Biol. Chem. 1990, 265, 21039-21047. [CrossRef]

24. Adham, I.M.; Nayernia, K.; Burkhardt-Göttges, E.; Topaloglu, Ö.; Dixkens, C.; Holstein, A.F.; Engel, W. Teratozoospermia in mice lacking the transition protein 2 (Tnp2). Mol. Hum. Reprod. 2001, 7, 513-520. [CrossRef]

25. Heidari, M.M.; Danafar, A.; Moezzi, F.; Khatami, M.; Talebi, A.R. The association between TNP2 gene polymorphisms and iranian infertile men with varicocele: A case-control study. Int. J. Reprod. Biomed. 2019, 17, 557-566. [CrossRef] [PubMed]

26. Sironen, A.; Hansen, J.; Thomsen, B.; Andersson, M.; Vilkki, J.; Toppari, J.; Kotaja, N. Expression of SPEF2 during Mouse Spermatogenesis and Identification of IFT20 as an Interacting Protein. Biol. Reprod. 2010, 82, 580-590. [CrossRef]

27. Sironen, A.; Uimari, P.; Iso-Touru, T.; Vilkki, J. L1 insertion within SPEF2 gene is associated with increased litter size in the Finnish Yorkshire population. J. Anim. Breed. Genet. 2012, 129, 92-97. [CrossRef]

28. Chen, M.; Yan, H.; Wang, K.; Cui, Y.; Chen, R.; Liu, J.; Zhu, H.; Qu, L.; Pan, C. Goat SPEF2: Expression profile, indel variants identification and association analysis with litter size. Theriogenology 2019, 139, 147-155. [CrossRef]

29. Sironen, A.; Kotaja, N.; Mulhern, H.; Wyatt, T.A.; Sisson, J.H.; Pavlik, J.A.; Miiluniemi, M.; Fleming, M.D.; Lee, L. Loss of SPEF2 function in mice results in spermatogenesis defects and primary ciliary dyskinesia. Biol. Reprod. 2011, 85, 690-701. [CrossRef]

30. Sha, Y.; Liu, W.; Wei, X.; Zhu, X.; Luo, X.; Liang, L.; Guo, T. Biallelic mutations in Sperm flagellum 2 cause human multiple morphological abnormalities of the sperm flagella (MMAF) phenotype. Clin. Genet. 2019, 96, 385-393. [CrossRef]

31. Ensembl. Available online: https: / / www.ensembl.org / Bos_taurus/Variation /Explore? db=core; $\mathrm{r}=4: 79295681-79296681 ; \mathrm{v}=\mathrm{rs} 4$ 3408735; vdb=variation; $\mathrm{ff}=9956999$ (accessed on 25 January 2021).

32. Sang, L.; Du, Q.-Z.; Yang, W.-C.; Tang, K.-Q.; Yu, J.-N.; Hua, G.-h.; Zhang, X.-X.; Yang, L.-G. Polymorphisms in follicle stimulation hormone receptor, inhibin alpha, inhibin bata A, and prolactin genes, and their association with sperm quality in Chinese Holstein bulls. Anim. Reprod. Sci. 2011, 126, 151-156. [CrossRef] [PubMed]

33. Nakayama, T.; Kuroi, N.; Sano, M.; Tabara, Y.; Katsuya, T.; Ogihara, T.; Makita, Y.; Hata, A.; Yamada, M.; Takahashi, N.; et al. Mutation of the follicle-stimulating hormone receptor gene $5^{\prime}$-untranslated region associated with female hypertension. Hypertension 2006, 48, 512-518. [CrossRef] [PubMed] 
34. Seok, O.S.; Ahn, J.M.; Mayo, K.E.; Cho, B.N. Developmental changes in inhibin- $\alpha$ gene expression in the mouse testis. Mol. Cells 2004, 17, 67-72.

35. Tang, K.Q.; Li, S.J.; Yang, W.C.; Yu, J.N.; Han, L.; Li, X.; Yang, L.G. An MspI polymorphism in the inhibin alpha gene and its associations with superovulation traits in Chinese Holstein cows. Mol. Biol. Rep. 2011, 38, 17-21. [CrossRef]

36. Wang, J.; Li, Z.J.; Lan, X.Y.; Hua, L.S.; Huai, Y.T.; Huang, Y.Z.; Ma, L.; Zhao, M.; Jing, Y.J.; Chen, H.; et al. Two novel SNPs in the coding region of the bovine PRDM16 gene and its associations with growth traits. Mol. Biol. Rep. 2010, 37, 571-577. [CrossRef]

37. Krause, W.; Bohring, C. Inhibin B as a marker of spermatogenesis. A new dimension in andrology. Hautarzt 2002, 53, 5-10. [CrossRef]

38. Meehan, T.; Schlatt, S.; O’Bryan, M.K.; De Kretser, D.M.; Loveland, K.L. Regulation of germ cell and sertoli cell development by activin, follistatin, and FSH. Dev. Biol. 2000, 220, 225-237. [CrossRef] [PubMed]

39. Boitani, C.; Stefanini, M.; Fragale, A.; Morena, A.R. Activin stimulates sertoli cell proliferation in a defined period of rat testis development. Endocrinology 1995, 136, 5438-5444. [CrossRef]

40. Buzzard, J.J.; Farnworth, P.G.; De Kretser, D.M.; O'Connor, A.E.; Wreford, N.G.; Morrison, J.R. Proliferative phase Sertoli cells display a developmentally regulated response to activin in vitro. Endocrinology 2003, 144, 474-483. [CrossRef]

41. Barakat, B.; O'Connor, A.E.; Gold, E.; de Kretser, D.M.; Loveland, K.L. Inhibin, activin, follistatin and FSH serum levels and testicular production are highly modulated during the first spermatogenic wave in mice. Reproduction 2008, 136, 345-359. [CrossRef] [PubMed]

42. Gao, Q.; Ju, Z.; Zhang, Y.; Huang, J.; Zhang, X.; Qi, C.; Li, J.; Zhong, J.; Li, G.; Wang, C. Association of TNP2 gene polymorphisms of the bta-miR-154 target site with the semen quality traits of Chinese Holstein bulls. PLoS ONE 2014, 9. [CrossRef] [PubMed]

43. Sironen, A.; Thomsen, B.; Andersson, M.; Ahola, V.; Vilkki, J. An intronic insertion in KPL2 results in aberrant splicing and causes the immotile short-tail sperm defect in the pig. Proc. Natl. Acad. Sci. USA 2006, 103, 5006-5011. [CrossRef] [PubMed]

44. Guo, F.; Yang, B.; Ju, Z.H.; Wang, X.G.; Qi, C.; Zhang, Y.; Wang, C.F.; Liu, H.D.; Feng, M.Y.; Chen, Y.; et al. Alternative splicing, promoter methylation, and functional SNPs of sperm flagella 2 gene in testis and mature spermatozoa of Holstein bulls. Reproduction 2014, 147, 241-252. [CrossRef] [PubMed] 